\title{
The Near Islands (the Aleutian Arc): History of Vegetation in the Holocene
}

\author{
O. I. Smyshlyaeva ${ }^{a,}$ *, E. E. Severova ${ }^{b}$, B. F. Khasanov ${ }^{a}$, O. A. Krylovich ${ }^{a}$, \\ E. A. Kuzmicheva ${ }^{a}$, and A. B. Savinetsky ${ }^{a}$ \\ a Severtsov Institute of Ecology and Evolution, Russian Academy of Sciences, Moscow, 119071 Russia \\ ${ }^{b}$ Biology Faculty, Moscow State University, Moscow, 119191 Russia \\ *e-mail: smyslyaevaol@gmail.com
}

Received August 24, 2020; revised September 4, 2020; accepted November 17, 2020

\begin{abstract}
The vegetation history of the Alcan Creek peat deposit on Shemya Island (the Near Islands of the Aleutian Arc) has been reconstructed. We chose this flat island because there are no volcanoes on it and they have less impact on the vegetation. The sedge tundra dominated until 7000 years ago. Then it was replaced by mire with a noticeable participation of Sphagnum and Equisetum during the Holocene warming maximum 7000-5000 years ago. Forb sedge-grass meadows spread about 4700 years ago as a result of a local change in humidity. As a consequence of cooling and leaching processes, heather tundra began to dominate in the inner part of the island about 3400 years ago.
\end{abstract}

DOI: $10.1134 / \mathrm{S} 1062359021040130$

\section{INTRODUCTION}

Investigations of the vegetation history in the Holocene are important for analysis of pathways of its formation, the modern state, and pathways to the future development; they provide a key to understanding the possible response of plants to the global climatic changes. Pollen analysis of the alluvial, lacustrine, and peat deposits remains the primary research method of vegetation history on a regional scale. This method is supported by the radiocarbon dating and offers substantiated insight into changes in vegetation and climate in the past.

This study was conducted on the Aleutian Islands, which is an archipelago of volcanically-derived islands extending approximately $2000 \mathrm{~km}$ from Alaska to Kamchatka. The chosen area is characterized by mild winters and cool summers, and low variation of the average annual temperatures, frequent fogs, protracted intervals of cloudiness, and high humidity (Byers, 1959). Atmospheric circulation and climatic changes are largely governed by the dynamics of the Aleutian Low, which is an area of low pressure near the Aleutian Islands (Rodionov et al., 2007). Vegetation of the islands is treeless and may be characterized as arctic tundra. The flora is predominantly represented by Pacific coastal species, as well as multiple Arcticalpine species with circumpolar distribution (Hulten, 1968).

The vegetation history investigations of the Aleutian Arc began in the middle of the past century by the pollen analysis of buried soils on Tanaga and Unalaska islands (Anderson and Bank, 1952). The soils pollen spectra at different depths showed the occurrence of at least one change of vegetation communities from heather dwarf shrubs to herbaceous communities in the Holocene history of Tanaga Island. What has been studied to date includes peat deposits on the islands of Umnak (Heusser, 1973), Carlisle (Kuzmicheva et al., 2019), and Atka (Heusser, 1990); two sediment cores from the peatland on Adak Island (Heusser, 1978; Noguchi et al., 2018); and mires on Attu (Heusser, 1990) and Bering (Kir'yanov et al., 1986) islands. Following the generalization of data obtained from different arc sectors, Heusser (1990) suggested that climate was the major factor in vegetation succession in the Holocene. No uniform climate patterns were evident in the western, central, and eastern sectors of the Aleutian Arc. Additionally, Heusser (1990) noticed that ashfalls of insignificant thickness, accompanying eruptions, might have influenced the vegetation by primarily causing changes in the species abundance in the communities rather than resulting in significant replacement of their composition. Ashfalls, following the larger eruptions, could have destroyed the vegetation communities almost entirely (Talbot et al., 2010). Volcanic activity was assumed to be weaker on the western islands than in the remaining part of the archipelago.

In the present study, flat Shemya Island (the Near Islands of the Aleutian Arc) without volcanoes was chosen for reconstruction of the vegetation dynamics in the western sector of the Aleutian Islands. Core 
Table 1. Field description of the Alcan Creak peat deposit (Shemya Island)

\begin{tabular}{c|l}
\hline Depth, cm & \multicolumn{1}{c}{ Peat description } \\
\hline $0-10$ & Modern plants \\
$10-20$ & Black dense sod interwoven by roots \\
$20-80$ & Black peat, very dense, poorly decomposed \\
$80-130$ & Peaty horizon, homogenous, yellowish, with inclusions of clay; plant remains are poorly decomposed \\
$130-205$ & $\begin{array}{l}\text { Peaty horizon, homogenous, brown, saturated with poorly decomposed plant remains, with inclusions } \\
\text { of clay. The 130- to 140-cm layer is of more intense gray color, with a fraction of large mineral particles. } \\
\text { A thin layer of sand occurs at a depth of } 165 \text { cm }\end{array}$ \\
$205-250$ & $\begin{array}{l}\text { Horizon is similar to the above, with a shade of yellow; small black spots can be seen vertically } \\
\text { Clayey horizon, very dense, grey, platy structure, contains a significant amount of plant remains: } \\
\text { lenses of sand and blue clay occur in the horizon }\end{array}$ \\
$260-264$ & $\begin{array}{l}\text { Clay horizon, brownish, interspersed with blue clay } \\
\text { Clayey horizon, yellow, inhomogeneous, ferruginous, with inclusions of crushed stone }\end{array}$ \\
\hline
\end{tabular}

sampled from Alcan Creek peat deposit lacked noticeable ash layers, which made it possible to observe the effect of climate phases on island vegetation communities in the Holocene irrespective of volcanic eruptions.

\section{MATERIALS AND METHODS}

Shemya Island (Near Islands) is a flat island without volcanoes located at $52^{\circ} 43^{\prime} 27^{\prime \prime} \mathrm{N}$ and $174^{\circ} 07^{\prime} 08^{\prime \prime} \mathrm{E}$ $\sim 4.5 \mathrm{~km}$ long, nearly $7 \mathrm{~km}$ wide; it has a land area of $\sim 15 \mathrm{~km}^{2}$. Two types of communities largely represent modern vegetation on the island (Kiseleva et al., 2002). Vegetation dominated by grasses, sedges, and with significant abundance of forbs occurs in the stream (less than 10-km long) valleys, lowlands, and slopes of various expositions. These communities reach the maximum diversity on the well-drained slopes of southern exposure. The second type of communities includes mosses and dwarf shrubs with considerable abundance of heath plants (Empetrum nigrum, Vaccinium vitis-idea), and Linnea borealis, as well as grasses and sedges, and occurs across various habitats (Kiseleva et al., 2002). In addition to these two types, dense meadow-type vegetation with the dominance of Elymus arenarius, Heracleum lanatum, and Senecio pseudo-arnica can be found on the hills not far from the seashore (Savinetrsky et al., 2010). Sedges are dominant in the vegetation communities in the waterlogging conditions (Kiseleva et al., 2002).

A $270 \mathrm{~cm}$ core was sampled from the Alcan Creek peat deposit in layers $10 \mathrm{~cm}$ thick within the Western Aleutians Archeological and Paleoecological Project (WAAPP) in 1994 (Table 1, Fig. 1). The mire is located in a stream valley in the northwestern part of the island $750 \mathrm{~m}$ from the coast and $35 \mathrm{~m}$ above sea level (Savinetsky et al., 2010). Plant fossils from five layers were taken to determine the age and accumulation rate by radiocarbon dating (Table 2). Samples were processed according to the technique described in the study (Kiseleva et al., 2002). The dating was done by the scintillation method in the Laboratory of Historical Ecology of the Severtsov Institute of Ecology and Evolution. The radiocarbon dates were calibrated to determine the calendar age and to calculate an age-depth model (Fig. 2) in the Bchron 4.2.6 package (Parnell, 2015) in the R v. 3.6.2 statistical environment (R Core Team, 2019) using the IntCal13 "terrestrial” calibration curve (Reimer et al., 2013). Details and mathematical tools employed in the package can be found in (Haslett and Parnell, 2008). Calibrated years are used farther.

Twenty-eight samples $1 \mathrm{~cm}^{3}$ in volume were collected from layers $10 \mathrm{~cm}$ thick for the pollen analysis. Chemical processing of the samples included boiling in $10 \% \mathrm{HCl}, 10 \% \mathrm{KOH}$, sieving, and acetolysis using the standard technique (Faegri and Iversen, 1975) with certain modifications (Chambers et al., 2011). Special markers were added during the chemical processing for determination of the spore and pollen concentrations (Stockmarr, 1973). Two tablets, containing Lycopodium clavatum spores from batch no. 483216, were added to each sample. Pollen and spores were identified using the atlas and keys (Reille, 1998, 1999) and the digital collection of pollen types (https://globalpollenproject.org). Despite the availability of the corresponding identifying keys (Warner and Chinnappa, 1986; Sarwar and Takahashi, 2014), 


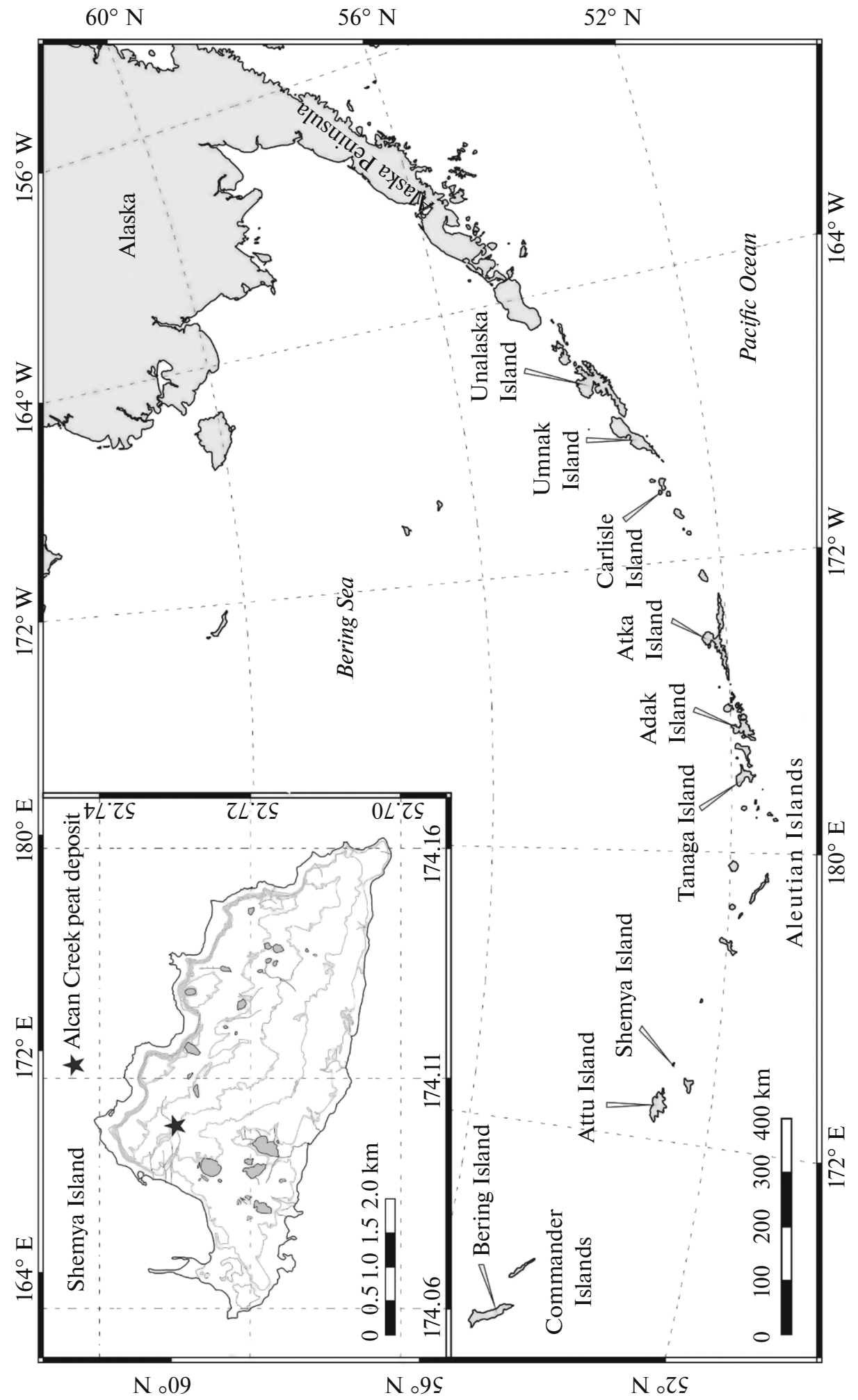

Fig. 1. Map of study areas. The Aleutian Islands. The insert shows Shemya Island; Alcan Creek peat deposit is marked with a star.

pollen of Ericaceae was identified to the family level, since the generic features could not always be distinguished. Pollen was counted using the Axioskop ZEISS light microscope at $\times 400$ magnifications to a minimum of 500 pollen grains in samples where possible. The percent composition was calculated from the sum of all pollen in the sample for pollen grains and the sum of pollen grains and spores in the sample 
Table 2. Radiocarbon dating of the Alcan Creek peat deposit (Shemya Island)

\begin{tabular}{l|c|c|r|r}
\hline \multirow{2}{*}{$\begin{array}{c}\text { Laboratory (sample) } \\
\text { no. }\end{array}$} & Depth, cm & $\begin{array}{c}\text { Radiocarbon } \\
\text { years, yr BP }\end{array}$ & \multicolumn{2}{|c}{ Calibrated age, yr BP } \\
\cline { 3 - 5 } & & $562 \pm 83$ & 830 & $570-1900$ \\
IEMAE-1199 & $20-30$ & $3221 \pm 75$ & 3620 & $3340-4260$ \\
IEMAE-1201 & $80-90$ & $4396 \pm 198$ & 5350 & $4700-6350$ \\
IEMAE-1200 & $130-140$ & $7562 \pm 104$ & 8425 & $8190-8810$ \\
IEMAE-1202 and 1204 & $200-210$ & $7924 \pm 320$ & 9365 & $8735-10755$ \\
IEMAE-1203 & $250-260$ & &
\end{tabular}

* The median and range are shown for midpoint depths of dated samples according to data derived from the model of the increase in the depth of the deposit built in the Bchron package (Parnell, 2015).

for spores. Tilia software v.2.0.41 was used to do the pollen diagrams (Grimm, 2015). Pollen zones were identified using stratigraphically constrained cluster analysis (CONISS) (Grimm, 2015).

\section{RESULTS}

Formation of the Alcan Creek peat deposit began $\sim 9500$ years ago (Table 2, Fig. 2). The mean accumulation rate is $0.27 \mathrm{~mm} /$ year. Deposition occurred at a relatively stable rate over the entire time period. An exception is the initial interval of the deposit formation circa 9200-8300 years ago $(250-200 \mathrm{~cm})$ when peat accumulated slightly more rapidly; that is, the mean accumulation rate was $0.56 \mathrm{~mm} /$ year at that time.

As a result of the pollen analysis, 34 types of pollen and spores were found, including six woody fossil pollen types ("trees and shrubs"), 21 herbaceous types ("herbs"), and seven types of spores (Figs. 3, 4). The Ericaceae (heath plants), Cyperaceae (sedges), and Poaceae (grasses) are the main dominant taxa. Abundance ranged from singular grains to $88.4 \%$ for Erica-

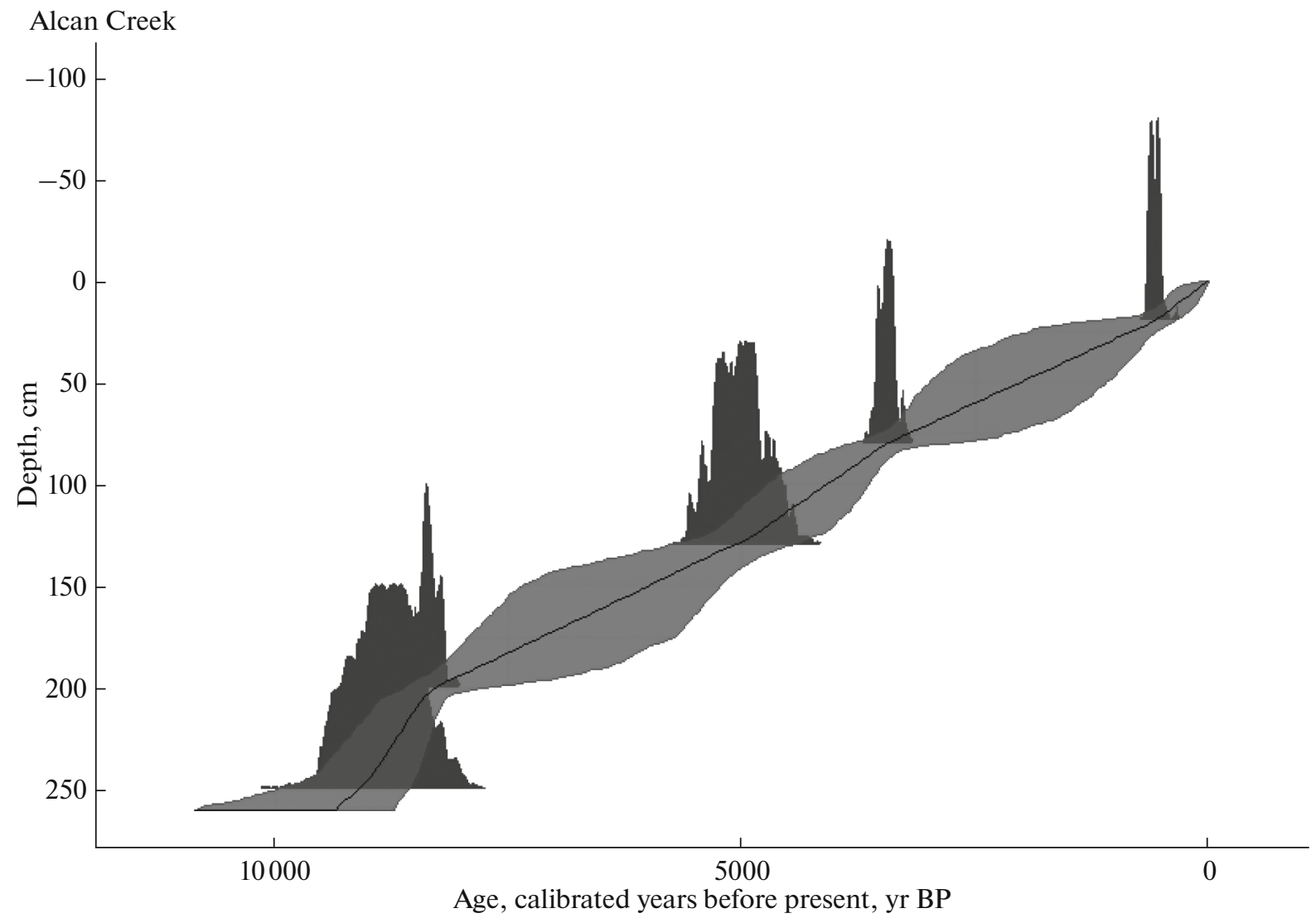

Fig. 2. Age-depth model of the Alcan Creek peat deposit. Calibrated dates appear in dark-gray; the $95 \%$-confidence interval is shown in gray. 
ceae, 0.5 to $72.3 \%$ for Cyperaceae, and 0.9 to $62.5 \%$ for Poaceae (Fig. 3). The total pollen concentration (TPC) varied between 30424 and 795972 grains $/ \mathrm{cm}^{3}$ (Fig. 4).

Pollen of Asteraceae (26.1\%), Cyperaceae (25.2\%), and Poaceae (21.4\%), as well as spores of Lycopodium annotinum (20.8\%), were dominat at the bottom of the peat deposit in the first two samples ( $~ 9500$ years ago). The TPC is on average 35642 grains $/ \mathrm{cm}^{3}$.

The zone from 9500 to 4700 years ago identified by cluster analysis (AlCr-1a, 270-120 cm) showed in the percent composition a dominance of Cyperaceae pollen-45\% on average (maximum level of TPC is 200972 grains $/ \mathrm{cm}^{3}$ ). The next abundant pollen type is Ericaceae, the percentage of which averages $17.6 \%$ (Figs. 3, 4). Interestingly, the concentration of Ericaceae pollen ranged from 1355 to 106900 grains $/ \mathrm{cm}^{3}$ in this part. The mean content of Poaceae pollen is $12.4 \%$; the concentration varies between 3708 grains $/ \mathrm{cm}^{3}$ (6700 years ago) and 346882 grains $/ \mathrm{cm}^{3}$ (4700 years ago). The pollen concentrations of Betula and Alnus show the highest concentration values within this zone, specifically, up to 4478 grains $/ \mathrm{cm}^{3}$ 8400 years ago and 5033 grains $/ \mathrm{cm}^{3} 9200$ years ago, respectively. Approximately 8700 years ago, spectra reveal singular Equisetum spores, the concentration of which reach 3192 grains $/ \mathrm{cm}^{3}$ 6500-6000 years ago and then drop to zero 5600 years ago. The Sphagnum spores emerge in the spectrum $\sim 8300$ years ago, increase their percentage to 6\% 6500-6000 years ago, and then almost entirely disappear from the spectrum $\sim 5100$ years ago. The interval $7800-5100$ years ago is noted for the emergence of undefined fossil pollen type, inaperturate grains with reticulate sculpture, the content of which reaches $16.9 \%$ (5100 years ago). On the Aleutian Islands, this type of pollen may belong to plants from the genera Triglochin or Potamogeton (Hulten, 1968).

The percentage of Poaceae pollen increases, whereas pollen grains of Ericaceae occur singularly in the composition of the pollen spectra approximately 4700 years ago (zone AlCr-1b, 120-80 cm, 47003400 years ago) (Figs. 3, 4). The concentrations of Apiaceae, Poaceae, and Fritilaria pollen increase to 74332,485911 , and 3097 grains $/ \mathrm{cm}^{3}$, respectively. The concentration of Ranunculus-type pollen spikes to 145566 grains $/ \mathrm{cm}^{3}$, drops to 7585 grains $/ \mathrm{cm}^{3}$ by the up of the zone (3400 years ago), and then disappears. The TPC is 481641-795972 grains $/ \mathrm{cm}^{3}$ 51003400 years ago; the values are the maximum in the entire deposit. The Lycopodium annotinum spores and pollen of Asteraceae largely disappear from the spectrum composition at the upper boundary of the $\mathrm{AlCr}$ $1 \mathrm{~b}$ zone $(3400$ years ago, $80 \mathrm{~cm})$.

Pollen of Ericaceae becomes dominant in the pollen composition 3400 years ago (AlCr-2 zone, 34000 years ago, $80-0 \mathrm{~cm}$ ) together with Cyperaceae pol- len. At the same time, the pollen concentration of sedges dropped (Fig. 4) compared to the preceding zone (to 2549-26346 grains $/ \mathrm{cm}^{3}$ ). The concentration of Ericaceae pollen is at the maximum $\sim 3400$ years ago, which is 252577 grains $/ \mathrm{cm}^{3}$; it gradually decreases to 42475 grains $/ \mathrm{cm}^{3}$ in the direction of the ground surface. A sharp drop from 53541 to 261505 grains $/ \mathrm{cm}^{3}$ is observed in the TPC value throughout the AlCr-2 zone. The content of the Poaceae pollen averages $5.1 \%$ except for the uppermost sample, where it reaches $16.4 \%$.

\section{DISCUSSION}

The formation of the Alcan Creek peat deposit began in the interior of Shemya Island $\sim 9500$ years ago (Figs. 1, 2). At that time, vegetation communities were largely represented by forbs-sedges tundra with the presence of the heath dwarf shrubs (Fig. 3). In the Aleutian Islands, the grass-sedge and forb-sedge tundra occurred in conditions sheltered from wind influence, often poorly drained (Heusser, 1973; Jordan and Krumhard, 2003). Similar to Shemya Island, Apiaceae and Lycopodium composed postglacial vegetation communities of the other islands of the archipelago (Heusser, 1973, 1978, 1990; Kuzmicheva et al., 2019). But differences in the dominants of the postglacial communities could have been significant, while the composition depended on local development conditions rather than the climatic conditions. Postglacial communities were represented by more humid sedge tundra on Umnak Island (Heusser, 1973). Sedges were also dominant on Adak Island, though the local conditions appear to have been drier (Heusser, 1978). The pollen spectra of Atka Island are similar to spectra of the Alcan Creek peat deposit; however, among plants of Atka Island, dominance belonged to grasses, which additionally confirms the drier conditions locally (Heusser, 1990). On Attu Island near Shemya, postglacial communities were represented by forbs with a high participation of Apiaceae and Asteraceae, which developed under conditions more sheltered from the wind (Heusser, 1990). In the Aleutian Islands, which almost entirely lacked terrestrial predators in the Holocene, dominance of Apiaceae and Asteraceae suggests the presence of a large colony of marine birds near the peat deposits, since certain species of these families prefer substrates rich in nitrogen (Kuzmicheva et al., 2019). The pollen spectra of the initial succession stages of Carlisle Island differ markedly with the dominance of heath plants due to the development of plants under strong wind influence near the coastal zone (Kuzmicheva et al., 2019). Modern communities similar to the above can be found on seashores or on slopes at higher elevations (Heusser, 1990; Jordan and Krumhardt, 2003). It can be presumed that the outward appearance and dominants composition of the postglacial vegetation communities were determined by local habitat conditions, the 


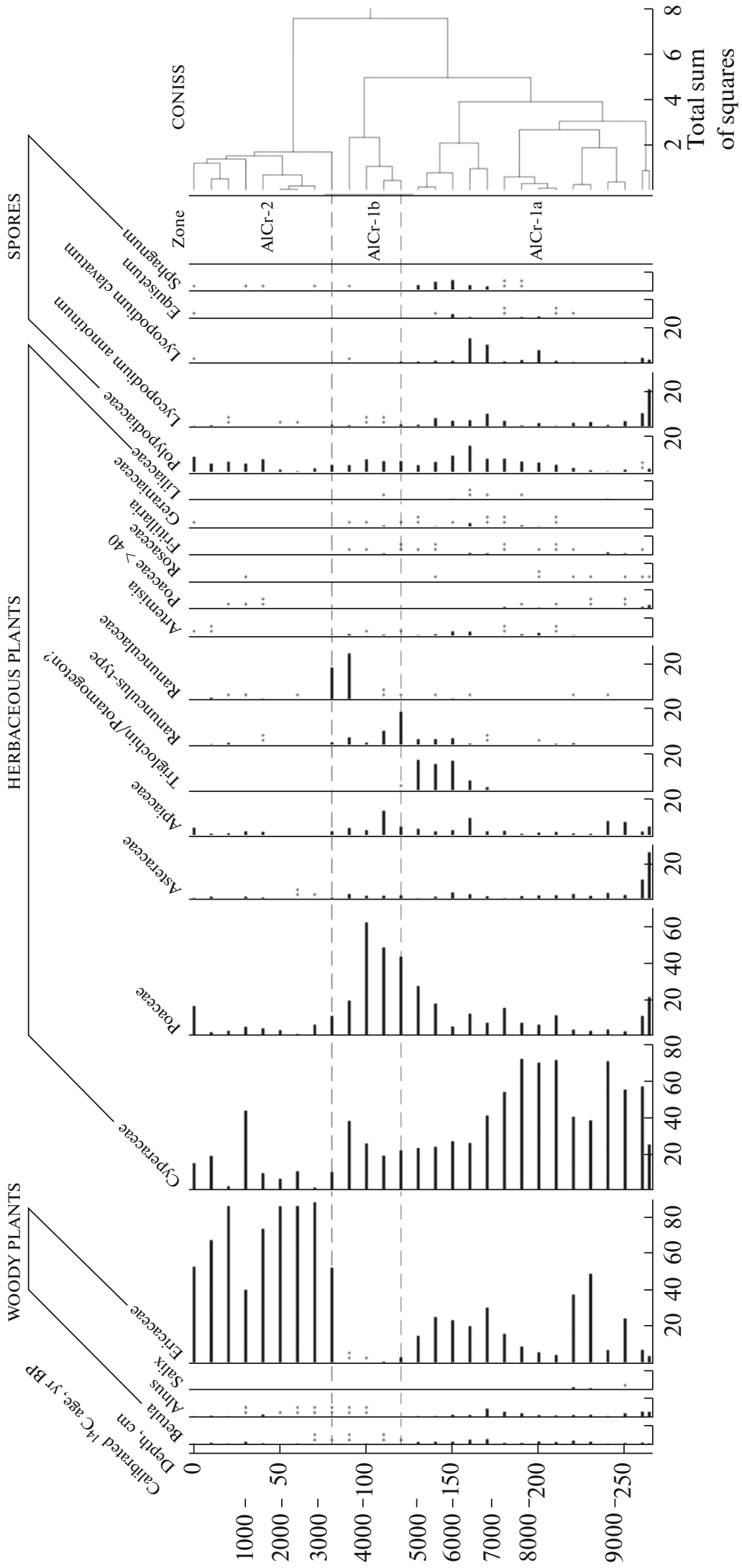

Fig. 3. Reduced diagram of pollen percent in the Alcan Creek peat deposit. AlCr-1a, $\mathrm{AlCr}-1 \mathrm{~b}$, and $\mathrm{AlCr}-2$ are pollen zones identified based on CONISS. The symbols "+" and "++" mark pollen grains encountered singularly. 
degree of protection from the wind, how well the substrate is drained, and its aeration, as well as the presence of bird colonies, altogether.

On Shemya Island, the forbs-sedges tundra with presence of the heath dwarf shrubs became significantly waterlogged approximately 7000 years ago (Fig. 3). Spores of Equisetum (Galka et al., 2018) and Sphagnum (Jordan and Krumhardt, 2003) indicate increased moisture availability. Inaperturate pollen, possibly belonging to plants from the genera Potamogeton or Triglochin (Figs. 3, 4), also indicates habitats with excess moisture (Hulten, 1968). The interval 7000-5000 years ago is considered to be the temperature maximum for the Bering Sea region in the Holocene (Kaufman et al., 2016), after which temperature gradually decreased. During the Holocene, Sphagnum had a high level of presence throughout relatively warmer climate phases in the composition of vegetation in the Alaskan Arctic bogs (Galka et al., 2018). It can be presumed that expansion of sphagnum mosses capable of retaining a large amount of water led to the formation of a sedge mire in the place of wet tundra. This trend is evident from the pollen analysis on Attu Island (Heusser, 1990), where waterlogging similarly occurred 7000 years ago due to presence of Sphagnum (Heusser, 1990). Thus, in the Aleutian Islands, the local increase in the moisture of plant communities could have been caused not only by periods of increased humidity in the region, but also by prolonged warming periods due to the increase in presence of sphagnum mosses.

Approximately 4700 years ago, Sphagnum disappeared from the spectra in response to the cooling that followed the temperature maximum; the sedge mire overgrows with the forb sedges-grasses meadows (Fig. 3). Similarly, the forbs-grasses meadows replaced the wet Sphagnum sedge mire on Attu Island (Heusser, 1990), but nearly a thousand year earlier, that is, 5500 years ago. Asynchrony in the vegetation dynamics on the island, neighboring Shemya, may be associated with the mountainous topography of Attu Island and the presence of ash layers in deposits. No similar successions are observed in response to the cooling that followed the temperature maximum on Adak, Atka, Carlisle, and Umnak islands (Heusser, 1973, 1978, 1990; Kuzmicheva et al., 2019). On the above islands, changes in vegetation communities could have largely been influenced by the volcanic ashfalls.

The interval $4700-3400$ years ago is characterized by the maximum values of pollen concentration in the Alcan Creek peat deposit (Fig. 4). At the same time, the increase in the pollen concentration could hardly be related to the features of deposit formation, since peat accumulation occurred uniformly throughout almost the entire history, according to data derived from the age-depth model (Fig. 2). This interval is characterized by a gradual decrease in temperatures that followed the Holocene maximum (Kaufman

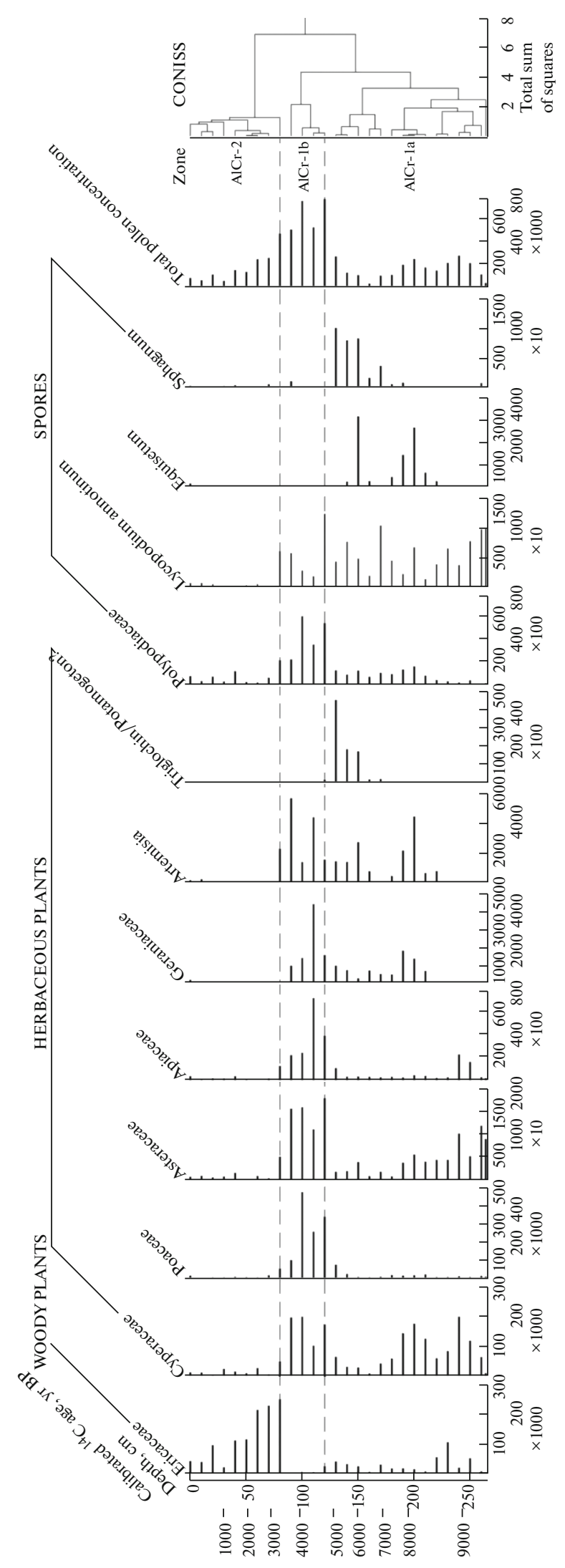

Fig. 4. Reduced diagram of pollen concentrations in the Alcan Creek peat deposit (grains $/ \mathrm{cm}^{3}$ ). AlCr-1a, AlCr-1b, and $\mathrm{AlCr}-2$ are pollen zones identified based on CONISS. 
et al., 2016). At the same time, relatively drier intervals 4000-2700 and 5000-3500 years ago have been reconstructed for the central and eastern sectors of the Aleutian Islands, respectively (Jones et al., 2009; Krawiec and Kaufman, 2014). It can be possible that drier conditions were favorable for an increase in productivity of many herbaceous taxa on oceanic islands with considerable overcast conditions during the cooling phase; however, none of the islands studied was reported to show an increase in the pollen concentration during this time interval. The values of the pollen concentration appear to have proved to be sensitive to volcanic eruptions, which had different effect on vegetation along the entire Aleutian Arc in the Holocene (Heusser, 1990). The ashfalls subsequent to eruptions with different thicknesses and chemical compositions might have led to both the complete destruction of vegetation and appreciable successional replacement of the communities (Neshataeva, 2009), thus precluding observation of the climate effect.

Circa 3400 years ago, forbs-grasses meadows are rather abruptly replaced by heath dwarf shrubs communities (Figs. 3, 4). The TPC and concentration of many palynotypes, except for Ericaceae, drop nearly to zero. Taxonomic diversity also declines. Based on the modern distribution of reconstructed communities, presumably, this replacement could have been caused by cooling, substantial intensification of wind activity, decrease in moisture in the region overall, or local changes in the hydrological regime. It could have been the interaction of all causes listed above. Noticeable cooling began in the Bering Sea region 4000 or 3000 years ago, according to different sources (Black, 1976, 1981; Thorson and Hamilton, 1986; Jordan and Krumhardt, 2003). Additionally, intensified storminess (Jordan and Krumhardt, 2003) could have contributed to the dominance of heath dwarf shrubs more adapted to the strong wind conditions (Heusser, 1978). Circa 3000 years ago, Attu Island also showed a well-marked peak of Empetrum nigrum heath dwarf shrub abundance (Heusser, 1990), which forms communities on the wind-exposed well-drained slopes in other regions (Breslina, 1987; Bunting, 1994). No replacement of herbaceous communities by the dwarf shrubs occurred on other Aleutian Islands, where vegetation was exposed to a stronger action of volcanic eruptions, due to appreciable cooling 40003000 years ago (Heusser, 1973, 1978, 1990).

The replacement of the herbaceous communities by the dwarf shrubs may be attributed not only to climatic factors. Intensive processes of leaching and washing away of soils and peat occurred on oceanic islands due to intensive precipitation (Birks and Peglar, 1979). Similar processes have been observed on Shetland Islands (Bunting, 1994) and on the Faroe Islands (Lawson et al., 2005). Heath dwarf shrubs gain competitive advantage in the conditions of nutrient deficiency compared to herbaceous species owing to the ericoid mycorrhiza (Makarov, 2019). On Shemya
Island, herbaceous communities may be presumed to be replaced by the dwarf shrub communities with the dominance of heath as a result of gradual leaching of the Alcan Creek peat deposit under the oceanic climate conditions. On Adak Island, the heath could have become dominants due to the similar leaching processes (Heusser, 1978; Noguchi et al., 2018), rather than in response to the drier conditions (Vaillencourt, 2013). The similar replacement of herbaceous communities by the heath took place on Attu Island (Heusser, 1990), which along with Shemya Island is located in the western sector of the ridge. On Attu, Ericaceae became abundant in the pollen spectra composition 6200 years ago, which may be also associated with mountainous topography and wind exposure; while their abundance in a composition of the spectra substantially increased $\sim 3000$ years ago (Heusser, 1990). Climatic factors and intensive leaching in the moisture conditions could have had a combined effect on vegetation in the Aleutian Islands in the Holocene.

Thus, the history of vegetation of Shemya Island (Near Islands of the Aleutian Arc) has been reconstructed according to the results of the pollen analysis of the Alcan Creek peat deposit. The peat deposit formed with a mean accumulation rate $0.27 \mathrm{~mm} /$ year. An interval of a relatively higher rate was observed 9200-8300 years ago $(0.56 \mathrm{~mm} /$ year $)$. A forb-sedge tundra with heath dwarf shrubs was dominant on the island in the wind-sheltered and poorly drained conditions approximately 9500 years ago. The Sphagnum abundance in the vegetation communities increased as a result of substantial warming 7000 years ago. In place of the wet tundra, sphagnum mosses formed conditions for the sedge mire with Equisetum emergence due to their water-holding capacity. Sphagnum disappeared from the pollen spectra in response to subsequent cooling $\sim 4700$ years ago, while the forb sedgegrass meadows formed in place of the mire in drier conditions. The interval $4700-3400$ years ago is characterized by the maximum levels of total pollen concentration in the Alcan Creek peat deposit, which could coincide with drier climate and lower storminess. On Shemya Island, herbaceous communities were replaced by communities with the dominance of heath dwarf shrubs 3400 years ago, which might have been related to a cooling phase in the Bering Sea region, which occurred $\sim 3000$ years ago.

\section{ACKNOWLEDGMENTS}

The authors thank Dixie West for organizing and joint participation in the expedition.

\section{FUNDING}

This study was supported by the Russian Foundation for Basic Research, project nos. 19-34-90071 and 18-04-00782 A. 


\section{COMPLIANCE WITH ETHICAL STANDARDS}

The authors declare that they have no conflict of interest.

This article does not contain any studies involving animals or human participants performed by any of the authors.

\section{OPEN ACCESS}

This article is licensed under a Creative Commons Attribution 4.0 International License, which permits use, sharing, adaptation, distribution and reproduction in any medium or format, as long as you give appropriate credit to the original author(s) and the source, provide a link to the Creative Commons licence, and indicate if changes were made. The images or other third party material in this article are included in the article's Creative Commons licence, unless indicated otherwise in a credit line to the material. If material is not included in the article's Creative Commons licence and your intended use is not permitted by statutory regulation or exceeds the permitted use, you will need to obtain permission directly from the copyright holder. To view a copy of this licence, visit http://creativecommons.org/licenses/by/4.0/.

\section{REFERENCES}

Anderson, S.T. and Bank, T.P., Pollen and radiocarbon studies of Aleutian soil profiles, Science (Washington, D.C.), 1952, vol. 116, no. 3004, pp. 84-86.

Birks, H.J.B. and Peglar, S.M., Interglacial pollen spectra from Sel Ayre, Shetland, New Phytol., 1979, vol. 83, no. 2, pp. 559-575.

Black, R.F., Geology of Umnak Island, eastern Aleutian Islands as related to the Aleuts, Arct. Antarct. Alp. Res., 1976, vol. 8 , no. 1 , pp. 7-35.

Black, L.T., Volcanism as a factor in human ecology: the Aleutian case, Ethnohistory, 1981, pp. 313-340.

Breslina, I.P., Rasteniya i vodoplavayushchie ptitsy morskikh ostrovov Kol'skoi Subarktiki (Plants and Water Birds of the Sea Islands of the Kola Subarctic), Leningrad: Nauka, 1987.

Bunting, M.J., Vegetation history of Orkney, Scotland; pollen records from two small basins in west Mainland, New Phytol., 1994, vol. 128, no. 4, pp. 771-792.

Byers, F.M., Investigations on Alaska volcanoes: geology of Umnak and Bogoslov Islands, Aleutian Islands, Alaska, Geol. Soc. Am. Bull., 1959, pp. 267-369.

Chambers, F.M., van Geel, B., and van der Linden, M., Considerations for the preparation of peat samples for palynology, and for counting of pollen and non-pollen palynomorphs, Mires Peat, 2011, vol. 7, pp. 1-14.

Faegri, K. and Iversen, J., Textbook of Pollen Analysis, Munksgaard, Copenhagen, 1975, p. 295.

Gałka, M., Swindles, G.T., Szal, M., Fulweber, R., and Feurdean, A., Response of plant communities to climate change during the late Holocene: palaeoecological insights from peatlands in the Alaskan Arctic, Ecol. Indic., 2018, vol. 85, pp. 525-536.

Grimm, E.C., Tilia for windows: pollen spreadsheet and graphics program, Version 2.41, 2015.
Haslett, J. and Parnell, A.C., A simple monotone process with application to radiocarbon-dated depth chronologies, J. R. Stat. Soc. Ser. C Appl. Stat., 2008, vol. 57, no. 4, pp. 399-418.

Heusser, C.J., Postglacial vegetation on Umnak Island, Aleutian Islands, Alaska, Rev. Palaeobot. Palynol., 1973, vol. 15 , no. 4 , pp. 277-285.

Heusser, C.J., Postglacial vegetation on Adak Island, Aleutian Islands, Alaska, Bull. Torrey Bot. Club, 1978, pp. 18-23.

Heusser, C.J., Late Quaternary vegetation of the Aleutian Islands, southwestern Alaska, Can. J. Bot., 1990, vol. 68, no. 6, pp. 1320-1326.

Hultén, E., Flora of Alaska and Neighboring Territories: A Manual of the Vascular Plants, Stanford Univ. Press, 1968.

Jones, M.C., Peteet, D.M., Kurdyla, D., and Guilderson, T., Climate and vegetation history from a 14.000-year peatland record, Kenai Peninsula, Alaska, Quat. Res., 2009, no. 2, pp. 207-217.

Jordan, J.W. and Krumhardt, A., Postglacial climate and vegetation on the western Alaska Peninsula, Alaska J. Anthropol., 2003, vol. 1, pp. 16-33.

Kaufman, D.S., Axford, Y.L., Henderson, A.C., McKay, N.P., Oswald, W.W., Saenger, C., Anderson, R.S., Bailey, H.L., Clegg, B., Gajewski, K., Hu, F.S., Jones, M.C., Massa, C., Routson, C.C., Werner, A., Wooller, M.J., and Yu, Z., Holocene climate changes in eastern Beringia (NW North America) - a systematic review of multi-proxy evidence, Quat. Sci. Rev., 2016, vol. 147, pp. 312-339.

Kir'yanov, V.Yu., Egorova, I.A., and Litasova, S.N., Volcanic ash on Bering Island (Commander Islands) from Holocene eruptions in Kamchatka, Vulk. Seism., 1986, no. 6, pp. $18-28$.

Kiseleva, N.K., Savinetskii, A.B., and Khasanov, B.F., Development of natural processes on Shemya Island in the Holocene, Izv. Akad. Nauk, Ser. Geogr., 2002, vol. 1, p. 97.

Krawiec, A.C.L. and Kaufman, D.S., Holocene storminess inferred from sediments of two lakes on Adak Island, Alaska, Quat. Res., 2014, vol. 82, no. 1, pp. 73-84.

Kuzmicheva, E.A., Smyshlyaeva, O.I., Vasyukov, D.D., Khasanov, B.F., Krylovich, O.A., Okuno, M., West, D.L., Hatfield, V.L., and Savinetsky, A.B., A 7300-yr-old environmental history of seabird, human, and volcano impacts on Carlisle Island (the Islands of Four Mountains, eastern Aleutians, Alaska), Quat. Res., 2019, vol. 91, no. 3, pp. 934952.

Lawson, I.T., Church, M.J., McGovern, T.H., Arge, S.V., Woollet, J., Edwards, K.J., Gathorne-Hardy, F.J., Dugmore, A.J., Cook, G., Mairs, K.-A., Thomson, A.M., and Sveinbjarnardotti, G., Historical ecology on Sandoy, Faroe Islands: palaeoenvironmental and archaeological perspectives, Hum. Ecol., 2005, vol. 33, no. 5, pp. 651-684.

Makarov, M.I., The role of mycorrhiza in transformation of nitrogen compounds in soil and nitrogen nutrition of plants: a review, Eurasian Soil Sci., 2019, vol. 52, no. 2, pp. 193205.

Neshataeva, V.Yu., Rastitel'nost' poluostrova Kamchatka (Vegetation of the Kamchatka Peninsula), Moscow: KMK, 2009.

Noguchi, M., Fujiki, T., Okuno, M., Gualtieri, L., Hatfield, V.L., Sarata, B., Torii, M., Wada, K., Nakamura, T., and West, D., Vegetation changes around Haven Lake, Adak Island, Central Aleutians, Alaska, determined from 
pollen analysis, Radiocarbon, 2018, vol. 60, no. 5, pp. 14831492.

Parnell, A., Bchron: radiocarbon dating, age-depth modelling, relative sea level rate estimation, and non-parametric phase modeling, R package version 4.1.1, 2015.

$\mathrm{R}$ Core Team, R: a language and environment for statistical computing, R Foundation for Statistical Computing, Vienna, Austria, 2019. https://www.R-project.org/.

Reille, M., Pollen et Spores d'Europe et d'Afrique du Nord, Marseille, 1998, suppl. 2.

Reille, M., Pollen et Spores d'Europe et d'Afrique du Nord: index, Marseille, 1999.

Reimer, P.J., Bard, E., Bayliss, A., Beck, J.W., Blackwell, P.G., Ramsey, C.B., Buck, C.E., Cheng, H., Edwards, R.L., Friedrich, M., Grootes, P.M., Guilderson, T.P., Haflidason, H., Hajdas, I., Hatte, C., Heaton, T.J., Hoffmann, D.L., Hogg, A.G., Hughen, K.A., Kaiser, K.F., Kromer, B., Manning, S.W., Niu, M., Reimer, R.W., Richards, D.A., Scott, E.M., Southon, J.R., Staff, R.A., Turney, C.S.M., and van der Plicht, J., IntCal13 and Marine 13 radiocarbon age calibration curves $0-50000$ years cal BP, Radiocarbon, 2013, vol. 55, no. 4, pp. 1869-1887.

Rodionov, S.N., Bond, N.A., and Overland, J.E., The Aleutian Low, storm tracks, and winter climate variability in the Bering Sea, Deep Sea Res. II: Top. Stud. Oceanogr., 2007, vol. 54, nos. 23-26, pp. 2560-2577.

Sarwar, A.K.M. and Takahashi, H., Pollen morphology of the tribe Phyllodoceae (Ericoideae, Ericaceae) and its tax- onomic significance, Bangl. J. Plant Taxon., 2014, vol. 21, no. 2, pp. 129-137.

Savinetsky, A.B., Kiseleva, N.K., Khassanov, B.F., Lefevre, C., and Corbett, D., Paleoenvironment-Holocene Deposits from Shemya Island, in The People at the End of the World: The Western Aleutians Project and the Archaeology of Shemya Island, Aurora Monogr. Ser., 2010, vol. 7.

Stockmarr, J., Determination of Spore Concentration with an Electronic Particle Counter, Danmarks Geologiske Undersøgelse, 1973.

Talbot, S.S., Talbot, S.L., and Walker, L.R., Post-eruption legacy effects and their implications for long-term recovery of the vegetation on Kasatochi Island, Alaska, Arct. Antarct. Alp. Res., 2010, vol. 42, no. 3, pp. 285-296.

Thorson, R.M. and Hamilton, T.D., Glacial Geology of the Aleutian Islands: Based on the Contributions of Robert F. Black, 1986.

Vaillencourt, D.A., Five-thousand years of hydroclimate variability on Adak Island, Alaska inferred from $\delta \mathrm{D}$ of n-alkanoic acids, Doctoral Dissertation, Northern Arizona University, 2013.

Warner, B.G. and Chinnappa, C.C., Taxonomic implications and evolutionary trends in pollen of Canadian Ericales, Can. J. Bot., 1986, vol. 64, no. 12, pp. 3113-3126.

Translated by E. Kuznetsova 